\title{
Bilişim Çağında ‘Gençlik, Din ve Değer’ Konularını Ele Alan Makaleler Üzerine Bir İnceleme
}

\author{
Fatma Kurttekin
}

\author{
Dr. Öğr. Üyesi, Sivas Cumhuriyet Üniversitesi (ROR ID: 04f81fm77) \\ İlahiyat Fakültesi, Din Eğitimi Anabilim Dalı \\ Assist. Prof. Dr., Sivas Cumhuriyet University \\ Faculty of Theology, Depermant of Religious Education \\ Sivas/Turkey \\ fkurttekin@cumhuriyet.edu.tr \\ ORCID: 0000-0002-5083-4746
}

\section{A Review on Articles Relating to 'Youth, Religion and Value' in the Information Age Abstract}

The increasing use of the internet and smartphones, especially with the pandemic, has led people to spend more time on different platforms. In the researches, it has been revealed that individuals especially youths actively use search engines such as Google, which facilitate the access to information as well as social media platforms such as Facebook (Fb), Instagram, Twitter. In fact, the expressions of "Molla Google" and "Hazreti Google" indicate its extensive usage among youth. However, it is difficult to say that the opportunities offered by the mass communication tools brought by the information age can always be used favorable and correctly. As a matter of fact, the question of what is the extent of the influence of the virtual world on the new meanings that can be attributed to values, especially change and degeneration in values, occupies the minds. Therefore, the problem of identification with values caused by this change, which has attracted attention in young people in recent years, is one of the issues that draw attention in researches. It is argued that the youth's relations with their families and their environment weakened and they became asocial, and at the same time they have become socialized in the virtual world; values such as respect, love and tolerance have been shaken. In this respect, the studies on the effects of the content provided by the virtual world on the youth's value perceptions were analyzed. Related articles were classified under

Bu makale, "Uluslararası İslam, Modernite ve Gençlik Sempozyumu”nda sözlü olarak sunulan ve özeti basılan "Home Office Gençlik: İnternet Çă̆ında ‘Gençlik, Din ve Değer’ Tartışması Üzerine Din Eğitimi Perspektifinden Bibliyografik Bir Değerlendirme” adlı tebliğin içeriği geliştirilerek ve kısmen değiştirilerek üretilmiş halidir. / This paper is the final version of an earlier paper called "Home Office Youth: A Bibliographic Evaluation on Debate of 'Youth, Religion and Value' In the Internet Age from the Perspective of Religious Eduction", its abstract previously printed, orally presented at "International Sypmposium on Islam, Modernity and Youth" symposium, the content of which has now be endeveloped and partially changed.

Intihal Taraması/Plagiarism Detection: Bu makale intihal taramasından geçirildi/This paper was checked for plagiarism Etik Beyan/Ethical Statement: Bu çalışmanın hazırlanma sürecinde bilimsel ve etik ilkelere uyulduğu ve yararlanılan tüm çalışmaların kaynakçada belirtildiği beyan olunur/It is declared that scientific and ethical principles have been followed while carrying out and writing this study and that all the sources used have been properly cited (Fatma Kurttekin).

Geliş/Received: 15 Mayıs/May 2021 | Kabul/Accepted: 30 Ağustos/August 2021 | Yayın/Published: 20 Eylül/September 2021 Atıf/Cite as: Fatma Kurttekin, "Bilişim Çağında ‘Gençlik, Din ve Değer' Konularını Ele Alan Makaleler Üzerine Bir İnceleme = A Review on Articles Relating to 'Youth, Religion and Value' in the Information Age”, Eskiyeni 45 (Eylül/September 2021), 781-795. https://doi.org/10.37697/eskiyeni.937521

CC BY-NC 4.0 | This paper is licensed under a Creative Commons Attribution-NonCommercial License 
two themes. The first of these themes is "youth, religion and digital media". The second is "youth, value and digital media". 26 of the articles on youth, internet, religion and value published through the DergiPark system in the last ten years (2010-2020) have been evaluated from the religious education perspective by using the literature review method. Almost all of the studies (with the exception of one) are field studies that present qualitative and quantitative data. In these studies, it was observed that the use of digital media for religious purposes in the relationship between youth, religion and value, marginalization, love-hatecyberbullying, and privacy as well as internet addiction problem were examined. The borderremoving structure of digital media affects the value perception and hierarchy of youth, but it creates an environment of competition and choice besides information pollution. As a result of the researches, it has been revealed that the opportunities offered by digital media may cause fluctuations in the value perception levels. In this context, the problem of supervision of technological tools that bring education and entertainment together, security risks and erroneous learning caused by misinformation, along with being exposed to pornography, images and advertisements in which violence and bad habits are normalized can cause many psychological, social, especially religious and moral problems. Therefore, it can be said that there is a need for new studies that will more clearly identify the value degeneration and for new contents of Religious Culture and Moral Knowledge (RCMK) course that will raise awareness of the youth against these problems.

\section{Keywords}

Religious Education, Youth, Religion, Value, Internet

\section{Bilişim Çağında ‘Gençlik, Din ve Değer’ Konularını Ele Alan Makaleler Üzerine Bir İnceleme}

\section{Öz}

İnternet ve akıllı telefonların özellikle pandemiyle birlikte artan kullanımları bireyleri farklı platformlarda daha fazla vakit geçirmeye yöneltmiştir. Yapılan araştırmalarda bireylerin özellikle gençlerin bilgiye erişimi kolaylaştıran Google gibi arama motorlarının yanında Facebook (Fb), Instagram, Twitter gibi dijital medya platformlarını aktif şekilde kullandıkları ortaya konulmuştur. Öyle ki, gençlerin dillerinden düşürmediği "Molla Google" ve "Hazreti Google" ifadeleri internetin gençler arasında yaygın kullanımına işaret etmektedir. Ancak, bilişim çağının getirdiği kitle iletişim araçlarının sunduğu imkanların her daim olumlu ve doğru kullanılabildiğini söylemek mümkün değildir. Nitekim değerlere yüklenebilen yeni anlamlar, özellikle değerlerdeki değişim ve dejenerasyonda sanal âlemin etkisinin boyutu nedir sorusu zihinleri meşgul etmektedir. Dolayısıyla son yıllarda gençlerde dikkat çeken bu değişimin yol açtığı değerlerle özdeşleşme problemi araştırmalarda dikkat çeken konulardan biridir. Gençlerin aileleri ve çevreleriyle ilişkilerinin zayıllayıp asosyalleştikleri aynı zamanda sanal alemde sosyalleştikleri; saygı, sevgi, hoşgörü gibi değerlerin sarsıldığı tartışılmaktadır. Bu açıdan çalışmada sanal alemin sunduğu içeriklerin gençlerin değer algılarına yönelik etkilerini konu edinen araştırmalar analiz edilmiştir. Literatür taraması yöntemiyle son on yıllık süreçte (2010-2020) DergiPark sisteminde yayınlanan gençlik, internet, din ve değer konulu 26 makale din eğitimi perspektifinden incelenmiştir. Ele alınan çalışmaların neredeyse tamamı (biri hariç) nitel ve nicel veriler sunan saha araştırmalarıdır. Söz konusu yıllarda yapılan çalışmalarda gençlik, din, değer ve dijital medya ilişkisinde dini amaçlı dijital medya kullanımı, ötekileştirme, sevgi-nefret-siber zorbalık, mahremiyet değerlerinin yanında internet bağımlılığı gibi sorunların irdelendiği görülmüştür. Mevcut veriler benzerlik ve farklılıklarına göre 
oluşturulan "gençlik, din ve dijital medya" ve "gençlik, değerler ve dijital medya" olarak iki tema altında değerlendirilmiştir. Dijital medyanın sınırları kaldıran yapısı gençlerin değer algı ve hiyerarşisini etkilemekte bilgi kirliğinin yanında bir rekabet ve seçim ortamı oluşturmaktadır. Araştırmaların sonucunda dijital medyanın sunduğu imkanların değer algı düzeylerinde dalgalanmalara yol açabileceğine dair bulgular ortaya çıkmıştır. Bu bağlamda eğitim ve eğlenceyi bir araya getiren teknolojik araçların denetim problemi, güvenlik riskleri ve yanlış bilgilenmenin yol açabileceği hatalı öğrenmelerin yanında pornografi, şiddet ve kötü alışkanlıkların normalleştirildiği imge ve reklamlara maruz kalınabilmesi psikolojik, sosyal, bilhassa dini ve ahlaki birçok probleme sebep olabilmektedir. Dolayısıyla değer dejenerasyonu karşısında daha net tespit edecek yeni çalışmalara ve gençleri bu problem karşısında daha iyi bilinçlendirecek Din Kültürü ve Ahlak Bilgisi (DKAB) ders içeriklerine ihtiyaç duyulduğu söylenebilir.

\section{Anahtar Kelimeler}

Din Eğitimi, Gençlik, Din, Değer, İnternet

\section{Giriş}

İnsanlar sosyal bir varlıktan e-sosyal varlıklara, belirli bir mekânda yüz yüze iletişimden sanal ortamlarda gerçekleşen iletişime geçmektedirler. "Düşünüyorum, öyleyse varım!" söyleminden "Dijital medya kullanıyorum öyleyse varıma!" doğru bir evrilme söz konusudur. Bu geçişin temel unsurları olan bilişim teknolojileri ve internetin kullanımı üzerine dünya genelinde 16-64 yaş aralığındaki bireylerle yapılan araştırmada \%63'ü interneti bilgi edinmek, \%56,3'ü arkadaş ve ailesiyle iletişimini sürdürmek ve bir şeylerin nasıl yapılacağını araştırmak için kullanırken eğitim ve öğretim temelli aktiviteler için kullanım oranı \%42,6 olarak tespit edilmiştir. Dolayısıyla yaklaşık kullanıcıların üçte ikisi için internet temel bilgi kaynakları arasında yer almaktadır. Son 5 yılda dijital medyada harcanan zaman 1,5 kat artmıştır. En çok ziyaret edilen siteler ise sırasıyla Google, Youtube ve Facebook'tur. Ülkemizde ise ilk sirayı alan Youtube'u (\%94,5), Instagram (\%89,5), WhatsApp (\%87,5), Facebook (\%79), ve Twitter $(\% 72,5)$ izlemektedir. Türkçe'nin en yaygın kullanılan 4 . web dili olması Türkçe bilen kişilerin yeni medya olanaklarına olan ilgisi ve kullanım süresiyle ilgili ipuçları vermektedir. Öyle ki, dijital medyada harcanan vakit Türkiye'de 2 saat 57 dakika ile 2 saat 25 dakikalık dünya ortalamasının üstündedir. 13 ile 65 ve yukarı yaş kategorilerinin hepsinde erkeklerin kadınlardan daha fazla dijital medyada vakit geçirdikleri görülmektedir (We Are Social and Hootsuite, 20.03.2021).

Yukarıdaki verilerden anlaşılacağı üzere hayatımızdan teknolojiyi çıkarmak söz konusu değildir. Nitekim geleceğe hazırlık için bu imkân ve gelişmelerden nasıl yararlanılacağı ve nasıl bir nesil yetiştirileceği ele alınması gereken temel konulardan biri olduğu söylenebilir. Bu konunun öznesi ise interneti en fazla ve en etkili şekilde kullanan gençlerdir. Onlar, dijital dünyayla entegre oldukça çevreleriyle etkileşimlerini asgari düzeye indirgeyebilmektedirler (İnce-Y1lmaz, 2020; Çelik, 2017; ŞahinYağc1, 2017). Bu durum kimliklerini şekillendiren din, ahlâk ve değerlere yönelik tutumlarını da etkileyebilmektedir (Güneş, 2018; Koç, 2017). Dolayısıyla bu çalışmada 2010-2020 yılları arasında DergiPark sisteminde dijital medyanın gençlerin değer algılarına olan etkisini konu edinen çalışmaların değerlendirilmesi amaçlanmıştır. 
Gençlerin dijital medyayı dini amaçlardan ziyade iletişimde kalmak için kullandıkları, dijital medyada maruz kaldıkları içeriklerin sevgi, saygı, tahammül, hoşgörü, mahremiyet gibi değer algılarını etkilediği varsayımı alanyazındaki bulgularla karşılaştırılmıştır. Ayrıca çalışmada şu sorulara cevap aranmıştır:

Söz konusu yıllarda yapılan çalışmalarda gençlik, din, değer ve dijital medya ilişkisinde hangi konular irdelenmiştir?

Araştırmalara göre gençlerin değer yönelimlerinde dijital medya kullanımının pozitif ya da negatif bir etkisi söz konusu mudur?

\section{Yöntem}

Bu çalışmada Türkiye'deki akademik dergi yayıncılığında açık erişim sistemi olan DergiPark'ta 2010-2020 yılları arasında “dijital medyada gençlik, din ve değer” konularında yürütülen çalışmalar literatür taramasına tabi tutulmuştur. Mevcut veriler benzerlik ve farklılıklarına göre oluşturulan temalar altında toplanarak incelenmiştir. Makalelerin bazısı hem din hem değer konusunu incelemiştir. Bu makalelerin ait oldukları temanın belirlenmesinde odaklanılan problem, alt problemler ve hipotezler göz önünde bulundurulmuştur.

Din, değer ve gençlik konusu 20. yüzyıldan itibaren sosyal bilimler alanında tartışılan temel konulardan birini oluşturmaktadır. 21. yüzyılın "bilişim çağı" olarak adlandırılmasıyla bu araştırmalara dijital medya da eklenmiştir. DergiPark sistemi üzerinde "dijital medya, değer, din, gençlik" anahtar kelimeleriyle tarama yapılmıştır. Tarama sonucunda makalelerin amaçları ve araştırma yöntemleri incelenmiş konu ile alakalı toplamda 26 makaleye ulaşılmıştır. 26 çalışmanın tamamı yapılan inceleme neticesinde konuları itibariyle iki tema altında toplanmıştır. Bu temalardan ilki gençlik, din ve dijital medya kullanımı; ikincisi gençlik, değer ve dijital medyadir.

Alanyazında Batı'da dinin dijital ortamda görünürlüğüne dair yürütülen çalışmalar örnek alınarak "sosyal medya dindarlığı (Oyman, 2016), sanal cemaatler (Rheingold, 1987), çevrimiçi din- çevrim dışı din (Campbell, 2012), gösterişçi dindarlık (Okumuş, 2006)" gibi yeni kavramların doğduğu teorik bir zemin oluşturulmuştur (Haberli, 2020; Furat, 2019). Zamanla saha çalışmalarında kullanılmak üzere dijital medya kullanımı, dijital medyaya güven, bilgi okuryazarlığı, dijital medya bağımlılığı, dindarlık ve değer ölçekleri uyarlanmış ve geliştirilmiştir.

\section{Bulgular ve Yorum}

Bulgular "gençlik, din ve dijital medya" ve "gençlik, değerler ve dijital medya" olarak iki tema altında ayrı ayrı ele alınmıştır.

\subsection{Gençlik, Din ve Dijital Medya}

Çalışmanın gençlik, din ve dijital medya teması altında ele alınan on makale medya kullanımının gençlerin din algılarına etkisi ile bilgi okuryazarlığı konularını incelemektedir. Araştırmaların tamamı saha çalışmalarından oluşmaktadır. 
Dini bilginin dijital medyada yer almasına yönelik tutumlar: Konuya yönelik çalışmalara bakıldığında, Vardı (2012) 18-34 yaş aralığında 244 kişinin dini içerikli internet kullanımına dair yaklaşımlarını tespit etmeyi amaçlamıştır. Elde edilen veriler sonucunda katılımcıların internet ortamında sunulan dini içerik ve hizmetlere yönelik olumlu tutuma sahip oldukları tespit edilmiştir. Dolayısıyla katılımcıların dini öğrenme ve öğretme gibi saiklerle interneti dini amaçlı kullanımlarının giderek arttı̆̆ belirtilmiştir. Makalede dini bilgi ve hizmetlere uzlaşmada kolaylık sağlayan dijital medyanın aynı zamanda kontrol mekanizmasının sağlıklı işlememesinden kaynaklanan dini bilgi eksikliği ve yanlışlıklarına dikkat çekilmiştir. Öyle ki aynı örneklem grubu ile bu çalışmanın devamı niteliğinde düşünülebilecek sanal âlemde yer alan dinî bilgilerin güvenilirliğine dair saha çalışması yürütülmüştür. Katılımcıların \%62,7'sinin internet ortamındaki dini bilgileri güvenilir bulmadıkları ortaya çıkmıştır (Vardı, 2013, 84). Benzer sonuca ulaşan Oyman (2016)'ın 14-30 yaş aralığındaki gençlerden anket yöntemi ile topladığı bulgular da dikkate alındığında dijital medya aracılığıyla dini bilgi edinmenin önemli olduğu fikrine sahip olan gençlerin dini içerikli bilginin güvenirliği söz konusu olduğunda aynı olumlu tutuma sahip olmadıkları söylenebilir. Nitekim katılımcılar bu bilgileri Diyanet İşleri Başkanlığı (DỉB) ve İlahiyat Fakülteleri gibi resmî kurumların web siteleri aracılığıla teyit etme tutumu sergilemişlerdir (Vard1, 2013; Oyman, 2016). İslamiyet'in ilk emri olan “oku"manın bilmeye ve anlatmaya teşviki dini otoriteleri sanal âlemde görünürlük kazanmaya ve rehberlik fonksiyonunu sürdürmeye yönlendirmiştir. Amazon firmasının ölçüm şirketi Alexa verilerine göre DİB, Türkiye'nin en fazla ziyaret edilen 500 sitesi arasında 189. sıradadır. Listede yer alan tek dini bilgi ve kaynak edinme sitesidir (Alexa, 23.03.2021). Öte yandan İpek ve Tavukçuoğlu'nun (2020) çalışmasında belirttiği gibi dijital medyada DİB gibi geleneksel dini otoritelerin konumunu paylaşan bilgiyi üreten/türeten makro otoritelerin varlığı da söz konusudur. Bu da 7'den 70'e herkesin rahatlıkla konuşabildiği din konusunda bilgi kirliliğinin ve önyargıların önüne geçilebilmek için bilgiye erişim, anlama, yorumlama becerisiyle birlikte bilgi okuryazarlığı düzeyini geliștirmeyi gerektirmektedir. Aksi takdirde bilgi kirliliği ve bireyselcilik sorununun peyda olması kaçınılmazdır. Aşkın varlıkla ilişkinin bireysel alana taşınması (Cevizci, 1999) olarak ifade edilebilecek dinsel bireycilik "inandığı gibi yaşamayıp yaşadığı gibi inanan” Starbucks'tan aldığı kahveyi yudumlarken elindeki iphone ile dünyaya bağlanan "anı yaşa” felsefesini düstur edinen seküler gençlik profiline (Koç, 2017: Türkiye Geneli Gençlik Araştırması, 20.03.2021; Türkiye'de Gençlik, 25.08.2021) zemin sunabilmektedir.

Dijital medyanın dini bilgi edinme için kullanımı: Oyman'ın yanında Bodur ve Korkmaz (2017), Kuşçalı (2019) ve Yavuz'un (2020) araştırmaları ilahiyat ve İslami ilimler fakültelerinde eğitim hayatlarına devam eden öğrencilerin sosyal medya kullanım düzeyleri ve amaçlarına odaklanmıştır. Bodur ve Korkmaz'ın çalışmasında "dindarlık ile sosyal medya kullanımı arasında bir ilişki olduğuna dair hipotez doğrulanamamıştır” (Bodur-Korkmaz, 2017, 330). Bununla birlikte erkeklerin kız öğrencilere göre daha fazla vakit geçirdikleri dijital medyanın (Bodur ve Korkmaz, 2017; 
Karsl1, 2019) temelde iletişimi sürdürmek ve eğlence için kullanıldı̆̆ı bulgulanmıştır (Oyman, 2016; Kuşçalı, 2019; Yavuz, 2020). Ortaya çıkan bu tabloya binaen dijital medyanın bireyin var olan ihtiyacını en kısa ve tatmin edici şekilde doyurmanın aracı olduğu yani araştırmaların "kullanımlar ve doyumlar” yaklaşımını (Shao, 2009) desteklediği söylenebilir.

Bu çalışmalar arasında Gürses ve İrk (2018) internet kullanımının gençlerin dini gelişimlerine etkisini kaleme almıştır. Gençlerin zaman kaybı ve dini vecibeleri yerine getirmekten alıkoyması gibi sebeplerle internet ile dinî inanç arasındaki ilişkiye olumlu bakmadıkları (Gürses ve İrk, 2018) ortaya çıkmıştır. Ayrıca Eken'in (2020) çalışmasında katılımcılar internet ortamında yer alan yanlış bilgilerin ve dini istismar eden materyallerin, Müslüman kimliğine yakışmayan olay ve haberlerin dini duyguları zedeleyebildiğini dile getirmişlerdir. Buna rağmen gençlerin giderek artan dijital medya kullanımda günaha girme, dinden çıkma korkusu, yanlış anlaşılma ve tepki alma endişesi taşımadan anonim olarak zihinlerini meşgul eden dini konularda araştırma ve irdeleme imkanlarının olmasının etkisi söz konusudur. Dijital medyanın gençler arasında dini amaçlı kullanımı genellikle fikıh ve ilmihal konularıyla ahiret inanc1, evrenin yaratılışı ve farklı dinler üzerine yoğunlaşmaktadır (İrk, 2015). Dolayısıyla bireylerin dijital medyayı değerlendirirken dayandıkları referanslar ile taşıdıkları dini kimliklerin onlara yüklediği rol, beklenti ve misyonun etkili olduğu söylenebilir.

Zamanın değişen şartlarında güncellenen gençlik olgusunu sosyal, bilişsel, duygusal ve fizyolojik yönleriyle tanımak onların arayışlarına sağlıklı cevap vermeye ve iletişim sürecinin başlatılmasına katkı sağlayacaktır. Çünkü akıntıya karşı kürek çekmek yerine "tehdit veya imkân” alanına dönüşebilen bu araçlardan en iyi şekilde nasıl faydalanabileceğine cevap bulmak gerekmektedir. Bu bağlamda internetin gençler üzerindeki etkisini ele alan Turanalp'ın (2016) çalışmasında yanlış ve zararlı bilgi, müstehcenlik ve mahremiyet ihlalleri, zaman ve ekonomik israf, bağımlılık sorunlarını ve bunların çözümü için atılabilecek adımlara değinilmiştir.

\subsection{Gençlik, Değerler ve Dijital Medya}

Değerler, kişinin benlik algısını ve bireylerle ilişkilerini düzenleyen ve şekillendiren unsurlardır. Değerlerin kişinin hayatını şekillendirici ve yönlendirici etkisinin olması, din olgusuyla güçlü ve doğrudan bir bağlantısı olduğunu göstermektedir. Bu organik bağ bir değerin taşıdığı anlamın kavranabilmesi için onun ne olduğunun ve ne olmadığının bilinmesini gerektirmektedir. Bununla birlikte toplumdan topluma, çağdan çağa var olan değere yüklenen anlamlar değişebilmektedir. Toplumda başarı, hoşgörü, sevgi denildiğinde kastedilen ile anlaşılan aynı mıdır? Bir değişim ya da anlam kayması olmuş mudur? Medyanın küreselleşmeye vurgusu bireyleri temel ve kişiler arası ilişkileri düzenleyen değerler üzerine düşünmeye, mevcut sıralamada (hiyerarşide) sorgulamaya mecbur bırakmaktadır. Dijital medyadaki içeriklerin çözüm değil, problem üreten algı ve tutumlara yönelten yaklaşımları insan onuruna yakışır hayat, güzellik, sorumluluk, özgürlük, itidal, sevgi değerlerinde algılama bo- 
zukluğuna yol açabilmektedir. Dolayısıyla anormalliği normal olarak benimseyen bireylerin yetişmesi, toplumun sahip olduğu ortak değer sistemini sarsabilmektedir.

Gençlik, değer ve dijital medya teması altında değerlendirilebilecek toplamda on altı makale tespit edilmiştir. Alanyazında farklı okul türlerindeki lise ve üniversite öğrencilerinin dijital medya kullanımı ile değer algıları üzerine farklı değişkenler ekseninde çeşitli çalışmalar yürütülmüştür. Değerleri söz konusu edilen çalışmaların bir kısmı belli bir değer üzerine odaklanırken (Özbolat, 2013; Macit, 2014; ÖnderCoşkun, 2018; Arslan- Çaylak, 2018; Cıng1, 2018; Korkmaz- Mehmedoğlu, 2018; Vatandaş, 2018; Karslı, 2019; Çınar, 2019; Ankaralı vd., 2019; Evyapar- Özbolat, 2020; Karsl1Aycan, 2020; Kocagöz vd., 2020) bir kısmı da birbiriyle bağlantısı olan bir değerler grubunu (Doğan, 2018; Meydan vd., 2019, İnan Kılıç, 2020) temel almıştır. Çalışmalardan elde edilen sonuçlar şöyledir:

Dijital medyanın değer algısına etkisi: Meydan vd. yaptı̆̆ı araştırmada sosyal medya kullanımlarının gençlerin aile, hayatın anlamı ve geleceğe hazırlıkla ilgili değerlerine etkisi incelenmiştir. Sosyal medyada geçirilen sürenin bireylerin sosyal medyaya güven, hayatı anlamlandırma ve geleceğe kendilerini hazırlama değerlerinde anlamlı bir farklılaşmaya yol açtı̆̆ı saptanmıştır (Meydan vd., 2019). Sosyal medya kullanım amacı ve süresi ile değer arasındaki ilişkiyi inceleyen bir başka çalışma İnan Kılıç’a aittir. Bu araştırmanın cevap aradığı sorulardan biri sosyal medya kullanım amacı ve süresinin gençlerin manevi-insani değerler eğilimlerini farklılaştırıp farklılaştırmadı̆̆ıdır (İnan Kılıç, 2020). Çalışmanın sonucunda sosyal medya kullanım amacı ve süresi ile insani-manevi değerler eğilimi arasında anlamlı bir farklılaşmanın olmadığı bulgulanmıştır (İnan Kılıç, 2020). Bu iki çalışmada ortaya çıkan anlamlı ve anlamsız farklılaşma örneklem grubunun farklı illerden oluşması (Zonguldak, Sinop), araştırmaya konu edinilen değer gruplarının birbiriyle aynı olmamasıyla açıklanabilir. Farklı eğitim kurum ve kademelerindeki öğrencilerin dijital medya kullanımlarının değer algısına etkisini sorgulayan bu tarz çalışmalarda (Ankaralı vd., 2019; Çınar, 2019; Meydan vd., 2019; İnan K1lıç, 2020) okullarda verilen eğitim kalitesi, okulların toplumdaki itibarları, sundukları imkanlar ve okul programlarında yer alan din eğitimi ile alakalı derslerin yoğunluğu ortaya çıkan tabloyu şekillendiren unsurlardır denilebilir.

Sevgi: Merhamet, hoşgörü, şefkat gibi değerlere kaynaklık eden sevgi dijital medyada en çok kullanılan değerdir. Instagram paylaşımlarının top trend ifadesi sevgidir (We Are Social and Hootsuite, 20.03.2021). Ortaokul 8. Sınıf öğrencilerinin sevgiye dair paylaşımlarının incelendiği Önder ve Coşkun'un araştırmasında anne-baba sevgisi, kardeş sevgisi, sporseverlik, vatanseverlik, hayvanseverlik, peygamber sevgisi ele alınan alt kategorileri oluşturmaktadır (Önder-Coşkun, 2018). Özellikle Peygamber sevgisine dair paylaşımların temelinde "beğenilmesi veya paylaşılması" gibi koşula dayalı bir faktörün yer alması öğrencilerin tutumlarını etkileyen bir unsur olarak değerlendirilmiştir (Önder-Coşkun, 2018, 101). Gençlerin paylaşımlarında takdir edilme, beğenilme ve onaylanma duygularının rol oynaması dijital medyanın duygusal tepkiler üzerine inşa edilmiş yapısına işaret etmektedir. Dolayısıyla dijital 
medyanın kişiyi hiç düşünmeden harekete geçirebilen dinsel duygularını tetikleyen paylaşımlar kutuplaşmaya ve fanatikleşmeye yol açabilmektedir. Bundan dolayı sevgi değerinin zıttını temsil eden ve toplumdaki birçok problemin kaynağı olan nefretin sanal âlemdeki yansıması siber zorbalık (Belsey, 2004) ve İslam'a hedef alan yönü İslamofobik söylem üzerine odaklanan çalışmalar da yürütülmüştür.

Nefret söylemi insanların algılarına müdahale ederek farklı düşünce, kültür, inanç mensubu kişi ve grupların hor görülmesine, dışlanmasına ve değersizleştirilmesine yönelik saldırı biçimi olarak tanımlanabilir. Microsoft'un "Dijital Nezaket Araştırması"na göre ülkemizde üç kişiden biri siber zorbalığa maruz kalmaktadır (Microsoft, 23.03.2021). Çalışmalarda cinsiyet, yaş ve dindarlık düzeyleri, problemli kullanımını etkileyen unsurlar olarak karşımıza çıkmaktadır (Cıngı, 2018; KorkmazMehmedoğlu, 2018). Özellikle Korkmaz ve Mehmedoğlu'nun araştırmasında "16-23 yaş grubunda" problemli internet kullanımının en yüksek olduğu ve dindarlık düzeyi ile negatif yönde anlamlı ilişkisinin (Korkmaz ve Mehmedoğlu, 2018, 51) bulunduğu ortaya çıkmıştır. Bu durum dinî inanç ve kimliğin bireyin diğerkâmlık, empati, duyarlılık ve sorumluluk değerlerine bağlllık düzeylerine olumlu yönde pozitif katk1 sağlamasıyla açıklanabilir.

Problemli internet kullanımı altında ele alınan ötekileştirme, ayrılma ve ayrıştırma ekseninde kendini her açıdan üstün görme tasavvuruyla merhamet ve hoşgörüdeki zafiyetin, dejenerasyonun sonucudur denilebilir. Sosyal medyada ötekileştirme dar çerçevede, kısa zamanda sınırlı veri ve genellikle dış görünüşe göre kategorize etme ve etiketleme eğilimidir. Ötekileştirmeyi konu edinen Özbolat (2013), Macit (2014), Vatandaş (2018) ve Özbolat- Evyapar'ın (2020) çalışmaları Facebook ve etkileşimli sözlüklerde toplumun bir kesimi tarafından olumsuz algı ve tutumların hedefi yapılan İmam-Hatip liselerine ve bu okulun mezunlarına odaklanmaktadır. Bu araştırmalarda İmam-Hatip kavramı ile ilişkilendirilen metaforlar, değerler ve eylem tipleri nelerdir sorusuna cevap aranmıştır. Özbolat'ın (2013) araştırması "ihlsözlük" diye adlandırılan etkileşimli sözlük ortamında "İmam-Hatipli dindar gençlik" kavramının özeleştirisini sunarken Macit (2014) ve Özbolat-Evyapar (2020) bu kimliği taşıyan bireylerin çeşitli kategoriler altında maruz kaldığı negatif ve dışlayıcı tutumlara dikkat çekmişlerdir. Vatandaş'ın (2018) araştırmasında ise kendilerini "dindar" ya da "Kemalist" olarak nitelendiren bireylerin birbirlerini ötekileştirdikleri saptanmıştır (Vatandaş, 2018, 430). Dijitalleşmeyle benliği şekillendiren bireyselcilik ve öznelleşme gibi sorgulamaya, eleştiriye ve dönüşüme alan açan yeni faktörler ve unsurlar ortaya çımıştır. Dolayısıyla internet, benlik ve benliğin sahip olduğu din ve değer algılarının gelişiminde rol oynayan bir faktördür demek yanlış olmayacaktır (Lövheim, 2004).

Ötekileştirme algısı ayrıca çocuk ve gençlerin hobi ve ilgi alanlarından biri olan dijital oyunlarda karşılaşılan bir unsurdur. Dijital oyunların ötekileştirme mecrasına dönmesi karşısında Gençlik ve Spor Bakanlığı toplumsal duyarlılık oluşturmak adına 2016 yılında İslamofobik unsurlar içeren 19 oyuna dair rapor yayınlamıştır (Bilgisayar Oyunlarında İslamofobi, 20.03.2021). Bu oyunların altına yapılan yorumları analiz 
eden Cıngı, "şiddet yanlısı ve öldürmekten zevk alan Müslüman” profili oluştuğunu saptamıştır (Cıngı, 2018, 66). İnsan onurunu zedeleyen, benlik saygısını azaltan bu nefret tutumu sosyal uyum ve birlikte yaşama kültürünün gelişiminin önündeki aşılması gereken engellerden biri olarak durmaktadır.

Mahremiyet: Dijitalleşmeyle birlikte artan tüketim kültürü kendisini dini alanda da göstererek dini sembol, simge ve göstergeleri ticari değeri olan metalara dönüştürmüştür (Demirzen, 2010; Sungur, 2014; İnce, 2018). Nitekim mahremiyet alanına giren örtünme ya da giyim tarzında gözle görülür bir değişim dikkat çekmektedir. Mahremiyetin dijital medyada yaşadığı dönüşümde neyin, hangi platformda hangi düzeyde paylaşılacağı, kimlerin bu içeriye erişim izni olacağı hususları rol oynayabilmektedir. Çünkü bu paylaşımlarla belli yaşam tarzları empoze edilebilmekte merak duygusu cazip hale getirilebilmektedir. Mahremiyet, dindarlık ve dijital medya ilişkine ele alan Arslan ve Çaylak (2018), Kocagöz vd. (2020), Karslı ve Aycan'ın (2020) çalışmalarında dindarlık düzeyi yüksek bireylerin paylaşımlarında daha tedbirli ve dikkatli davrandığı tespit edilmiştir. Bununla birlikte Müslüman kadınlar ile erkeklerin dijital medyada yaptıkları paylaşımların farklı yorumlandığı, genç Müslümanların çağın şartlarını kimliklerine entegre ettikleri ve dinin araçsallaştırıldığı dile getirilmiştir (Arslan- Çaylak, 2018; Kocagöz vd., 2020; Karslı- Aycan, 2020). Özellikle Kocagöz vd.'nin dindarlık ile mahremiyet arasında bulguladığı "zayıf korelasyon" (Kocagöz vd., 2020, 92) daha detaylı tartışılması ve araştırılması gereken bir husustur.

Dünya genelinde 16-64 yaş aralığındaki bireylerin kişisel verilerin kötüye kullanımını önemsenme oranı \%33,1 iken Türkiye'de oran \%29,3'tür. Dolayısıyla ülkemizin kişisel verileri kötüye kullanma konusunu en az önemseyen ülkelerden biri olmas1 (We are social and Hootsuite, 20.03.2021) mahremiyet konusunda bilinçlenmeye ihtiyaç olduğuna işaret etmektedir. Ayrıca 2013'de Bitdefender tarafindan dünya genelinde 19 bin ebeveynle yürütülen araştırmaya göre internet ortamında pornografik sitelere ulaşma yaşı altıya düşmüştür (Bitdefender, 20.03.2021). Bunun yans1ması ülkemizin internet akışında 49. sırada yer alan pornografik içerikli siteye yapılan yoğun ziyarette görülebilmektedir (Alexa, 23.03.2021). Merak duygusunun gayrimeşru yollarla sağlıksız bir şekilde doyurulması cinsiyet rollerini, kadın-erkek ilişkisini ve toplumsal ahlâkı tehdit etmektedir. Bu sağlısıı durum aynı zamanda aşırılığın başka bir boyutu olan başkalarının fotoğraflarına gereğinden fazla odaklanma olarak ifade edebileceğimiz "photolurking" denilen e-hastalığa da davetiye çıkarabilmektedir.

Bağımlılık: Türkiye İstatistik Kurumu'nun (TÜIK) araştırmasına göre 2020 yılında 16-74 yaş aralığındaki bireylerin internet kullanım oranları \%75,3'ten, \%79'a ulaşmıştır (TÜIK, 2020). 16-24 yaş arası gençlerin 2019 yılı internet kullanma oranı ise \%92,4'tür (TÜİK, 2019). Günün yaklaşık dörtte birini (CNN, 19.02.2021) dijital medyada geçiren genç nüfusun neredeyse tamamı gelişim döneminin getirdiği tereddüt, bunalım, sorumluluk ve duyarlılığı adeta körelten bağımsızlık ve özgürlük isteğiyle yeni bağımlılıklara koşmaktadır. Aile içi tartışmaların temel sebeplerinden biri olan internet, gençlerin \%62,8’i (5021 kişi) için “olmazsa olmaz bir ihtiyaçtır” (Türkiye 
Geneli Gençlik Araştırması, 20.03.2021). Altında çeşitli sebeplerin yattığı aşırılı̆̆ın getirdiği fomo, nomofobi, photolurking gibi saplantılı davranışları içeren bağımlılık sadece internetin farklı hizmetlerinden uzak kalma düşüncesinin bile bireylerde yoksunluğa, öfkeye, kaygıya ve mutsuzluğa yol açması olarak tanımlanabilir. Bu bağımlılık çocuk ihmal (Sabah, 14.12.2019) ve istismarlarından ölümlere (cinayet, intihar) yol açacak geniş bir boyuta ulaşmıştır (Habertürk, 20.01.2015; The Sydney Morning Herald, 31.03.2010).

Bağımlılık problemini ele alan Karslı (2019) üniversite öğrencilerinin bağımlılık düzeyleri ve dindarlık ilişkisini, Ankaralı vd. (2019) Anadolu İHL öğrencilerinin başarı düzeylerine bağımlılık seviyelerinin etkisini, Çınar (2019) ise lise öğrencilerindeki içki, sigara internet gibi bağımlılık tutumlarının değer algılarına ve yabancılaşma olgusuna tesirini konu edinmiştir. Doğan'ın lise öğrencilerinin bağımlılık tutumlarının değer yönelimleri üzerine kaleme aldığı çalışmasında değerlerin görecelilik özelliğini (Rokeach, 1973) destekler şekilde cinsiyete bağlı farklılaşma bulgulanmıştır. "Güç, haz ve uyarılım” değerleri söz konusunda olduğunda bağımlılık puanlarını yükselten pozitif, insani değerler söz konusu olduğunda ise negatif yönlü bir eğilim tespit edilmiştir (Doğan, 2018, 263, 282). Farklı eğitim kademelerindeki öğrencilerin bağımlılık tutumlarını çeşitli değişkenler açısından ele alan bu makaleler dini şuur ve değer algısı düzeyi ile internet bağımlılığı arasında ters ilişki olduğunu göstermiştir.

\section{Sonuç ve Değerlendirme}

Din ve dinin beslediği değerler ile birlikte bilişim çağının getirisi olan teknoloji ve internetin sunduğu olanaklar toplumsal yapının şekillenmesinde göz ardı edilemeyecek bir role sahip olmuştur. Öyle ki, toplumların geleceğini inşa eden gençlerin din, değer ve dijital medya ile ilişkisini farklı boyutlarıyla inceleyen yazın gün geçtikçe genişlemektedir.

Eğitim ve eğlenceyi bir araya getiren teknolojik araçların denetim problemi, güvenlik riskleri ve yanlış bilgilenmenin yol açabileceği hatalı öğrenmelerin yanında pornografi, şiddet ve kötü alışkanlıkların normalleştirildiği imge ve reklamlara maruz kalınabilmesi psikolojik, sosyal, bilhassa dini ve ahlaki birçok probleme sebep olabilmektedir. Gelişmeler bedenin rahatına odaklanan ama ruhu ve beyni rahatsız eden olgular meydana getirebilmektedir. Nitekim her gün hem basılı hem de görsel işitsel medyaya yansıyan maddi ve manevi rahatsızlıklara sebep olan maddelerin kullanımın artması ve meşru görülmesi, tartışmalara neden olan cinsel yönelim ve kimliklendirme, şiddet, ötekileştirme, bölücülük gibi haberler değerlerde medyana gelen dejenerasyonun göstergesidir. Bu açıdan din, değer ve dijital medya ile gençlik arasındaki ilişkiye odaklanan çalışmaların dini amaçlı dijital medya kullanımı, dijital medya kullanımının değerlere ve değer yönelimine etkisi ve din-değer algısında doğurduğu problemler şeklinde değerlendirilebilir. Bu konuların tamamı literatür taraması ve söylem/içerik analiziyle birlikte anket, ölçek ve mülakat tekniklerini içeren nicel yöntemlerden faydalanılarak incelenmiştir. Ülke genelinde değerler çalışmalarında Schwartz'ın değer ölçeği (Mehmedoğlu, 
2006), bağımlılık söz konusu olduğunda Young bağımlılık ölçeği çoğunluk tarafından tercih edilmiştir. Makalelerin ortaya koyduğu sonuçlar ise genelde dijital medyanın dini bilgi edinmeden ziyade iletişim kurmak ve sosyalleşmek için kullanıldığını göstermekle birlikte, djiital medya kullanımı ile dindarlık düzeyi arasındaki negatif eğilimli ilişkinin yabancılaşma ve sorunlu değer algısı karşısında sağlıklı ve gelişim düzeyine uygun din eğitiminin bireylere ayakları yere daha sağlam basan ve tedbirli bir yaklaşım sergilemesi noktasında görev ve bilinç kazandırdığını ortaya koymaktadır. Çünkü insanın hayatını şekillendiren kaynağını inançtan alan değerler davranışlara tesir etmektedir.

Yapılan araştırmaların bulguları çerçevesinde bilgiye ulaşımı kolaylaştırırken, s1nırları ortadan kaldıran teknolojik gelişme ve globalleşmenin gençlerde ruhsal gerilim ve benlik arayışlarını daha da karmaşık hale getirebildiği anlaşılmaktadır. Gençlerin dijital medyada karşılaştıkları yaşam tarzlarını göz önünde bulundurarak kıyaslama yaptıkları ve ikilemler yaşadıkları söylenebilir. Gördüklerini ve öğrendiklerini kendince yorumlayarak içselleştirebilmektedirler. Cevap bulamayan içsel çelişkiler, özenti kültürü kendinden ve sahip olduğu değerlerden uzaklaşmaya sebep olabilmektedir. Hayalini kurduğu hayat tarzını sınırlandıran her türlü otoriteye baş kaldırmanın zeminindeki "özgürlük” algısı, yabancılaşmayla birlikte gençlerde ilk etapta "Ben de onlar gibiyim!"e, bir süre sonra “Aslında birbirimize benziyoruz!"a dönüşebilmektedir. Alternatif üzerinden girilen kendini inşa sürecinde açı veya örtük belli bir dini kimlik veya değere yönelik nefret söylemleri ve fobik yorumlar tesirinde okuduğunu, gördüğünü ve dinlediğini değerlendirilebilmektedir. Dolayısıly duygusal tepkiler üzerine inşa edilen yapısıyla dijital medya kaçınılmaz olarak kutuplaşmaya ve fanatikleşmeye yol açabilmektedir. Bu noktada yaşanan değişimler kapsamında öğretim programları gözden geçirilerek din eğitimi temelinde değer eğitimine eşlik eden duygu eğitimine ihtiyaç duyulmaktadır. Ayrıca mahremiyet algısını da dönüştüren dijital medyanın sebep olabileceği problemlerin önüne geçebilmek için gençleri bilinçlendirecek mahremiyet ve ahlâk eğitimi çalışmalarına odaklanılması gerekmektedir.

Dijital ortamlarda herkesin yorum yapma ve görüş beyan etme imkânının bulunması uzakları yakınlaştırırken bilginin alındığı kaynağa yönelik otantiklik ve güven sorunlarını gündeme taşımaktadır. Farklı kaynaklardan hızlı, değişime açık olarak aktarılan bilginin üst sınırın olmaması aynı oranda bilgi kirliliği tehlikesini doğurmaktadır. Dijital medya ortamında edinilen hatalı bilgilerin neticesinde dini vecibeler ve itikadi konularda ciddi problemlerle karşılaşılabilmektedir. Ayrıca "özgürlük alanı" dijital medya önyargılardan arınık diyalog sürecine imkân tanımakla birlikte farklılıkların kaybolmaması adına bazı referans noktalarının altını çizerek radikal dediğimiz unsur ve düşüncelerin ağırlık kazanmasına yol açabilmektedir. Dolayısıyla dijitalleşmeyle yaygınlaşan bağımsız, bireysel öğrenme ve bilgi edinme, bu süreçte sorumluluğunun farkında olan ve sorumluluğunun gereklerini yerine getirme kabiliyetleriyle donanmış birey yetiştirmeyi gerektirmektedir. Bilgiyi elde etme, anlama, yorumlama, geliştirme ve paylaşma noktasında bilinçli bir gençlik 
profili için Din Kültürü ve Ahlâk Bilgisi (DKAB) derslerinde ve öğretmen yetiştiren fakültelerin eğitim programlarında üst düzey düşünme becerileri kazandıracak içeriklere, medya ve bilgi okuryazarlığı konularını yer verilmesi çözüme yönelik atılabilecek adımlardan biridir (Furat, 2015; Furat, 2019; İpek-Tavukçuoğlu, 2020). Bu becerilerin bir getirisi de internet bağımlllı̆ı sorununun ortadan kalkmasına yardımcı olmasidır.

Dijital medya araçlarının değer eğitiminde bir firsata dönüşmesi izleme ve denetim mekanizmasının iyi çalışmasının yanında bütün paydaşlarının konuyla ilgili yeterli bilgi ve donanıma sahip olmasıyla mümkündür. Ancak sorumluluk kullanıcı konumundaki bireylerdedir. Toplumu bireyler, toplumun inanç ve değerleri de bireyleri şekillendirmektedir. Sağlıklı toplumun korunması ve devam ettirilmesi çağın getirilerini yakalayabilecek becerilerle kendini donatabilmenin yanında barışçl bir ortamda özünü kaybetmeden düşüncelerini ve tepkilerini dile getirip kimliğini ve değerlerini sunabilen gençler yetiştirecek ülkenin iç dinamiklerinden güç alan eğitim özelde din eğitimi programlarından geçmektedir.

\section{Kaynakça}

Alexa. “Top Sites in Turkey”. Erişim 23.3.2021. https://www.alexa.com/topsites/countries;7/TR https://www.alexa.com/siteinfo/diyanet.gov.tr\#card_topkeywords; https://www.alexa.com/siteinfo/qiqitv.info

Arslan, Ali- Çaylak, Melek. "Tesettür Giyimi Etkileyen Tüketim Kültürü Faktörleri Üzerine Uygulamalı Bir Araştırma”. Akademik İncelemeler Dergisi 13/1 (Nisan 2018), 41-70.

https://doi.org/10.17550/akademikincelemeler.396263

Ankaralı, Handan - Ünal, Erkam - İpekçi, Muhammed Ali - Tazim, Ömer Faruk - Türk, Ömer Tarık - Atasoy, Halil - Yıldız, Ömer Faruk - Araç, Hamza - Aydın, İshak - Karaman, Muhammet İhsan - Yelek, Mahmut. "Beyoğlu Anadolu İmam Hatip Lisesi Öğrencilerinde İnternet ve Sosyal Medya Bağımlılık Düzeyi, Başarı ile İlişkisi ve Bağımlılık Üzerine Etkili Faktörler”. Kalemname 4/8 (December 2019), 301-333.

Belsey, Bill. “Cyberbullying”. Erişim 20.03.2021.http://www.cyberbullying.ca

Bitdefender, "Kids and Online Threats". Erişim 20.03.2021. https://www.bitdefender.com/ media/materials/white-papers/en/Bitdefender-CaseStudy-Kids.pdf

Bodur, Hüsnü - Korkmaz, Sezai. “ỉlahiyat Öğrencilerinde Sosyal Medya Kullanımı ve Dindarlık İlişkisi”. Kahramanmaraş Sütçü İmam Üniversitesi İlahiyat Fakültesi Dergisi 30 (December 2017), 329-335.

Campbell, H. "Understanding the Relationship between Religion Online and Offline in a Networked Society". Journal of the American Academy of Religion 80/1 (2012), 64-93.

Cevizci, Ahmet. Felsefe Sözlüğü. İstanbul: Paradigma Yayınları, 1999.

Cıngı, Mustafa. "Dijital Oyunseverlerin İslamofobi İçerikli Oyunlara Bakışı”. Medya ve Din Araştırmaları Dergisi 1/1 (Haziran 2018), 49-72.

CNN Türk. "Türkiye'de her gün bir kişi 8 saatini internette geçiriyor! İşte en çok kullanılan uygulamalar" (19.02.2021). https://www.cnnturk.com/teknoloji/turkiyede-her-gun-1-kisi8-saatini-internette-geciriyor-iste-en-cok-kullanilan-uygulamalar?page=4.

Çelik, Merve. "Üniversite Öğrencilerinin Sosyal Medya Bağımlılık Düzeylerinin İncelenmesi: Kültür Üniversitesi Öğrencileri Üzerine Bir Araştırma”. İstanbul Ticaret Üniversitesi Akademik Arşiv Sistemi. Erişim 20.04.2021. http://acikerisim.ticaret.edu.tr/xmlui/handle/11467/1594 
Çınar, Fatih. “Gençlik Değerler ve Bağımlılık Profili Üzerine Bir Araştırma”. Süleyman Demirel Üniversitesi İlahiyat Fakültesi Dergisi 43 (Aralık 2019), 164-186.

Doğan, Mebrure. "Ergenlerin Değer Yönelimleri ve Değer Yönelimlerinin İnternet Bağımlılığıyla İlişkisinin İncelenmesi”. Uluslararası Sosyal ve Eğitim Bilimleri Dergisi 5/10 (Aralık 2018), 263-285. https://doi.org/10.20860/ijoses.475240

Eken, Metin. “Modern Görsel Kültürde M Nesli'nin Online İnanç Pratikleri”. Bilimname 43 (Kasim 2020), 31-71. https://doi.org/10.28949/bilimname.762744

Evyapar, Mehmet Ertuğrul - Özbolat, Abdullah. “Ötekileştirilen Dindar Gençlik: ‘İmam Hatipler Kapatılsın' Facebook Grubu Örneği”. İlahiyat Akademi 12 (Aralık 2020), 75-96.

Furat, Ayşe Zişan. “Medya ve Din: Din Eğitimi Açısından İmkân mı, Tehdit mi?”. Dijitalleşen Din (Medya ve Din 2). Ed. Mete Çamdereli- Betül Önay Doğan- Nihal Kocabay Şener. 325-363. İstanbul: Köprü Kitapları, 2015.

Furat, A. Z. "Din Eğitimi Ekseninde Türkiye'de Medya ve Din Araştırmaları". Medya ve Din Araştırmaları Dergisi 2/1 (2019), 29-51.

Gürses, İbrahim- İrk, Esra. “İnternet Kullanımı ve Ergenlerin Dini Gelişimleri Üzerine Bir Araştırma”. Uludağ Üniversitesi İlahiyat Fakültesi Dergisi 27/1 (2018), 109-135.

Haberli, Mehmet. "Dijital din Araştırmalarında Konu ve Yaklaşımlar”. İnsan ve Toplum Bilimleri Araştırmaları Dergisi 9/2 (2020), 879-902.

Habertürk. “Internet kafede öldü” (20.1.2015). https://www.haberturk.com/ekonomi/tekno loji/haber/1032639-internet-kafede-olum

İrk, Esra. İnternet Kullanımının Ergenlerin Dini Gelişimine Etkisi. Bursa: Uludağ Üniversitesi, Sosyal Bilimler Enstitüsü, Yüksek Lisans Tezi, 2015.

İnan Kılıç, Ayşe. "Lise Öğrencilerinin Manevi- İnsani Değerler Eğilimi”. Cumhuriyet İlahiyat Dergisi 24/2 (Aralık 2020), 807-831. https://doi.org/10.18505/cuid.765415

İnce Mustafa- Yılmaz, Mesut. "Ergenlik Çağındaki Çocukların Sosyal Medya Kullanım Alışkanlıklarının Yalnızlaşmaya Etkisi.” Gümüşhane Üniversitesi İletişim Fakültesi Elektronik Dergisi 8/2 (Eylül 2020), 1111-1144.

İpek, Fatih - Tavukçuoğlu, Mustafa. “Yüksek Din Öğrenimi Gören Öğrencilerin Bilgi Okuryazarlığı ve Epistemolojik İnanç Düzeyleri Üzerine Bir Araştırma”. Necmettin Erbakan Üniversitesi İlahiyat Fakültesi Dergisi 49/49 (June 2020), 259-302.

Karslı, Necmi. "Gençlerde İnternet Bağımlılı̆̆ı ve Dindarlık İlişkisi”. Ondokuz Mayıs Üniversitesi İlahiyat Fakültesi Dergisi 46 (Haziran 2019), 225-260. https://doi.org/10.17120/omuifd.526893

Karslı, Bahset - Aycan, Sezen. "Instagram ve Mahremiyet: Dindar Muhafazakâr Kadınların Paylaşımları Örneği”. Turkish Academic Research Review 5/2 (Haziran 2020), 245-266. https://doi.org/10.30622/tarr.725695

Kocagöz, Elif - Göksu, Nusret - Bakan, İsmail - Karakuş, Fatma Nur. "Mahremiyet ve Dindarlık Perspektifinden Sosyal Medya Platformlarında Görsel Paylaşımının İncelenmesi: KSÜ Ö ğrencileri Üzerinde Bir Uygulama". Kahramanmaraş Sütçü İmam Üniversitesi İktisadi ve İdari Bilimler Fakültesi Dergisi 10/1 (Haziran 2020), 83-101.

Korkmaz, Sezai -Mehmedoğlu, Ali Ulvi. “Dindarlık, Siber Zorbalık ve Problemli İnternet Kullanımı İlişkisine Dair Nicel Bir Araştırma”. Dini Araştırmalar 21/53 (Haziran 2018), 35-54. https://doi.org/10.15745/da.433507

Kuşcalı, Ali. "İslami İlimler Fakültesi Öğrencilerinin Sosyal Medya Kullanım Motivasyonlarının İncelenmesi". Simetrik İletişim Araştırmaları Dergisi 1/2 (July 2019), 100-110.

Lövheim, Mia. "Young People, Religious Identity and the Internet". Religion Online: Finding Faith on the Internet. ed. Lorne L. Dawson - Douglas E. Cowan. 59-73. London: Routledge, 2004. 
Macit, Mustafa. “Sosyal Medyada “İmam Hatipli” Temsilleri: Kolektif Bir Kimlik Söylemindeki Sosyal-Bilişsel İzdüşümler”. Atatürk Üniversitesi Türkiyat Araştırmaları Enstitüsü Dergisi 51 (2014), 379-394.

Mak Danışmalık ve Yeditepe Üniversitesi. “Türkiye Geneli Gençlik Araştırması 2020”. Erişim 20.03.2021. https://www.makdanismanlik.org/mak-danismanlik-genclik-arastirmasi/

Mehmedoğlu, Ali Ulvi. “Illahiyat Fakültesi Öğrencilerinin Değer Yönelimleri ve Dindarlık-Değer ile İlişkisi (M.Ü. İlahiyat Fakültesi Örneği)”. Marmara Üniversitesi İlahiyat Fakültesi Dergisi 30/1 (2006), 133-167.

Meydan, Hasan - Aybey, Salih - Dikmen, Fatmanur - Dikmen, Mustafa. “Sosyal Medya ve Gençlik Değerleri: Zonguldak’ta Liselerde Öğrenim Gören Gençler Üzerine Bir İnceleme”. Türkiye Din Eğitimi Araştırmaları Dergisi 7 (Haziran 2019), 125-143.

Microsoft. "Digital Civility Index Reports 2021”. Erişim 23.03.2021. https://www.microsoft.com/en-s/digitalskills/digitalcivility?activetab=dci_reports:primaryr4, https://query.prod.cms.rt.microsoft.com/cms/api/am/binary/RE4MJEF

Okumuş, Ejder. “Gösterişçi Dindarlık”. Dinbilimleri Akademik Araştırma Dergisi 6/3 (2006), 17-35.

Oyman, Nihat. "Sosyal Medya Dindarlığı”. Kahramanmaraş Sütçü İmam Üniversitesi İlahiyat Fakültesi Dergisi 28 (December 2016), 125-167.

Önder, Selçuk- Coşkun, Sevgi. “Sakarya Ölçeğinde 8. Sınıf Öğrencilerinin Sosyal Medyada Sevgi Değerini Yansıtan Paylaşımları Üzerine Nitel Bir Araştirma”. Journal of Political Administrative and Local Studies 1/2 (Ekim 2018), 93-111.

Özbolat, Abdullah. “İhlsözlük’te Dindar Gençliğin Özneleşmesi: İmam Hatipli, Ahlaklı ve Entelektüel”. Birey ve Toplum Sosyal Bilimler Dergisi 3/2 (Haziran 2014), 51-72.

Rheingold, Howard. "Virtual Communities: Exchanging Ideas through Computer Bulletin Boards". Whole Earth Review. Erişim 31.3.2021.

https://journals.tdl.org/jvwr/index.php/jvwr/article/view/293

Rokeach, M. The Nature of Human Values. New York: The Free Press, 1973.

Sabah. "Henüz 3.5 yaşında ama İngilizce konuşuyor... Ailesi şoke oldu” (14.12.2019). https://www.sabah.com.tr/yasam/2019/12/14/henuz-35-yasinda-ama-ingilizce-konusu yor-ailesi-soke-oldu.

SEKAM, Sosyal Ekonomik ve Kültürel Araştırmalar Merkezi. “Türkiye'de Gençlik Gençliğin Özellikleri, Sorunları, Kimlikleri ve Beklentileri”. Erişim 25.08.2021.

http://sekam.com.tr/images/resimler/468b1dd1.pdf

Shao, Guosong. "Understanding the Appeal of User- Generated Media: A Uses and Gratification Perspective". Internet Research 19/1 (2009), 7-25. http://dx.doi.org/10.1108/10662240910927795

Sungur, Erol. "Postmodern Tüketim Kültürü ve Değișen Müslüman Kimliği”. Recep Tayyip Erdoğan Üniversitesi İlahiyat Fakültesi Dergisi 3/5 (Aralık 2014), 131-165.

Şahin, Cengiz -Yağcl, Mustafa. "Sosyal Medya Bağımlılığı Ölçeği- Yetişkin Formu: Geçerlilik ve Güvenirlik Çalışması”. Ahi Evran Üniversitesi Kırşehir Eğitim Fakültesi Dergisi 14/1 (2017), 523-538.

T.C. Gençlik ve Spor Bakanlığı. "Bilgisayar Oyunlarında İslamofobi”. Erişim 20.03.2021. https:/yayinlar.gsb.gov.tr/public/online/0071_OyunlardaIslamafobiTR/files/assets/basic -html/page11.html

The Sydney Morning Herald, "Internet addicts guilty of starving baby to death" (31.05.2010). https://www.smh.com.au/technology/internet-addicts-guilty-of-starving-baby-to-death20100531-woeu.html.

TÜiK, Türkiye İstatistik Kurumu. "Hanehalkı Bilişim Teknolojileri (BT) Kullanım Araştırması, 2020”. Erişim: 23.03.2021. https://data.tuik.gov.tr/Bulten/Index?p=Hanehalki-BilisimTeknolojileri-(BT)-Kullanim-Arastirmasi-2020-33679 
TÜiK, Türkiye İstatistik Kurumu. “İstatistiklerle Gençlik, 2019”. Erişim 23.03.2021. https://tuikweb.tuik.gov.tr/PreHaberBultenleri.do?id=33731

Turanalp, Muhammed Fatih. "İnternetin Ergenlere Olumsuz Etkileri Üzerine Din Eğitimi Temelli Bir Yaklaşım”. Marife Dini Araştırmalar Dergisi 16/1 (Nisan 2016), 111-132.

Vardı, Recep. "İnternet Kullanıcılarının Dini İçerikli Kullanım Alışkanlıkları”. Harran Üniversitesi İlahiyat Fakültesi Dergisi 28/28 (Aralık 2012), 101-138.

Vard1, Recep. “İnternette Yer Alan Dini İçerikli Bilginin Güvenilirliği”. Bozok Üniversitesi İlahiyat Fakültesi Dergisi 3/3 (Temmuz 2013), 79-87.

Vatandaş, Saniye. "Farklı İdeolojik Kimlikler Açısından Sosyal Medyanın Anlam ve Önemi”. Akdeniz Üniversitesi İletişim Fakültesi Dergisi Özel Sayıs1 29 (2018), 414-434. http://dx.doi.org/10.31123/akil.454219

We Are Social and Hootsuite, "Digital in 2021". Erişim 20.03.2021 https://wearesocial.com/digital2021.

Yavuz, Sefer. “Sosyal Medya Kullanım Amaçları Üzerine Bir Araştırma: İlahiyat Fakültesi Öğrencileri Örneği”. Bozok Üniversitesi İlahiyat Fakültesi Dergisi 17/17 (Haziran 2020), 99-132. 